\title{
Correction to: The Welfare State: Will It Stay or Will It Go?
}

\section{Correction to:}

Chapter 5 in: R. Solli et al., Searching for New Welfare Models, https://doi.org/10.1007/978-3-030-58228-9_5

The original version of the book was inadvertently published with the below errors:

In Page 82, the sentence "Anna Coote and Andrew Percy (2020), however, are of the view that UBI is enough." should have been "Anna Coote and Andrew Percy (2020), however, are of the view that UBI is not enough."

The chapter has now been corrected and approved by the author.

The updated version of the chapter can be found at https://doi.org/10.1007/978-3-030-58228-9_5

(C) The Author(s) 2021

R. Solli et al., Searching for New Welfare Models, https://doi.org/10.1007/978-3-030-58228-9_6 